\title{
Is There a Value Paradox of E-learning in MBA Programs?
}

\author{
Nitza Geri \\ The Open University of Israel \\ Raanana, Israel \\ nitzage@openu.ac.il
}

\author{
David Gefen \\ Drexel University \\ Philadelphia, USA \\ gefend@drexel.edu
}

\begin{abstract}
Academic institutions invest considerable resources in improving the website quality of their MBA courses, in the hope of increasing student retention and willingness to recommend the programs to others. Despite this investment, it seems that the old "keep it simple" rule is also true for e-learning. Data collected from students enrolled in a blended distance learning MBA program at the Open University of Israel, shows that the students were most satisfied with the simple and relatively inexpensive e-learning tools, which did not require their active participation. The paper discusses bounded rationality and attention economy as suggested theoretical explanations for this phenomenon, as well as practical implications for academic institutions and educators.
\end{abstract}

Keywords: Value of Online Learning Systems, Blended Learning, E-Learning, Distance Learning, Bounded Rationality, Attention Economy, Student Retention.

\section{Introduction}

E-learning has become a strategic necessity for many organizations engaged in education or training (Hiltz \& Turoff, 2005; Neumann, 1994). Academic institutions invest money, lecturers spend time and efforts answering students and supervising online activities, and websites are loaded with enrichment materials. Utilizing these resources, students are engaged in online activities, such as reading and posting messages in online discussion forums, checking out relevant links to other websites, and reading current newspaper excerpts. The question arises then, academically as well as practically, what is the relative value of all these activities?

There are many different values of e-learning services: they may increase student satisfaction (Levy, 2006), or enhance the learning process (Hiltz \& Turoff, 2002), and therefore, increase student retention. Nevertheless, not all e-learning services are of equal value. Some distance learning environments or tools may be more effective than others (Alavi Marakas, \& Yoo, 2002; Rovai \& Jordan, 2004), and students may regard some activities as much more valuable than others (Levi, 2006).

Material published as part of this publication, either on-line or in print, is copyrighted by the Informing Science Institute. Permission to make digital or paper copy of part or all of these works for personal or classroom use is granted without fee provided that the copies are not made or distributed for profit or commercial advantage AND that copies 1) bear this notice in full and 2) give the full citation on the first page. It is permissible to abstract these works so long as credit is given. To copy in all other cases or to republish or to post on a server or to redistribute to lists requires specific permission and payment of a fee. Contact Publisher@InformingScience.org to request redistribution permission.
Since the value of E-learning provided information is relative and depends on the user and the circumstances (Ahituv, 1980, 1989), we relate to three groups of users: academic institutions, teachers, and students.

Student retention is one of the most important challenges facing distance education institutions (Eastmond, 1995; Rovai, 2002; Tresman, 2002; Woodley, 
2004; Guri-Rosenblit, 2005). As more and more academic institutions embed distance e-learning elements into their programs (Alavi \& Leidner, 2001; Hiltz \& Turrof, 2005) and incorporate distance or blended learning into their programs, the research questions grow in importance (Hirschheim, 2005). Thus, from an academic institution perspective, the value of e-learning should be measured by its effectiveness in increasing student retention and willingness to recommend the program to others.

The value of e-learning to students depends on many things. Among these are the field of study and the purpose of study. We chose to examine the value of e-learning to MBA students, since their motives for study are usually different from those of other graduate students and also because this is a very popular field that serves as a major income resource for many institutions. The time these students can invest in learning is limited, as most of them also work full time and sometimes also have a family to take care of. As a result of this balancing act, students need to set priorities. And so, they miss classes, make other compromises, and some of them adopt a satisficer approach. Simon (1957) suggested that satisficing decision makers aspire to reach a satisfactory solution, and not necessarily the optimal one (Ronen, Pliskin, \& Pass, 2006, pp. 14-18). In our context, a student who adopts a satisficer approach would aspire to successfully complete the courses by achieving a passing grade (or some other level of aspiration, e.g., an average grade of $80 \%$ out of $100 \%$ ), and would invest the least amount of effort required to achieve this goal. Even if indeed students would like to study more, and attain the highest grades, or broaden their knowledge, they have limited attention (Simon, 1971; Davenport \& Beck, 2000, 2001). The flexibility of e-learning and distance education may help these students. Therefore, it is especially interesting to examine the value of various e-learning services to MBA students.

The strategic need to invest in e-learning is a budget burden constraint in academic organizations and a strain on teachers' limited time. This may be especially important to new academics who must excel in both teaching and research in order to get tenure. Hence, on one hand they believe that they need to invest in their courses' websites to achieve high student evaluations, and on the other hand, they should engage in academic research and other activities. Adopting Simon's (1957) satisficer concept, teachers need to know how much effort to should invest in developing their websites and what tools are most valued by students.

The proposed model outlines the influence of auxiliary e-learning tools on student retention and willingness to recommend the program to others. The findings show that the students were most satisfied with the simple and relatively inexpensive e-learning tools which did not require active participation. The findings are discussed from a satisficing approach and a bounded rationality and attention economy perspective.

\section{The Suggested Model}

Figure 1 presents the proposed research model and delineates the influence of various types of auxiliary e-learning services on student retention and willingness to recommend the program to others.

The value of e-learning to academic institutions stems from its influence on student retention and willingness to recommend the program to other prospective students. E-learning is expected to increase both retention and student satisfaction (Simpson, 2003; Levy, 2007).

H1: Student satisfaction with e-learning overall quality positively influences willingness to recommend the program to others.

$\mathrm{H} 2$ : Student satisfaction with e-learning overall quality reduces inclination to withdraw the program. 


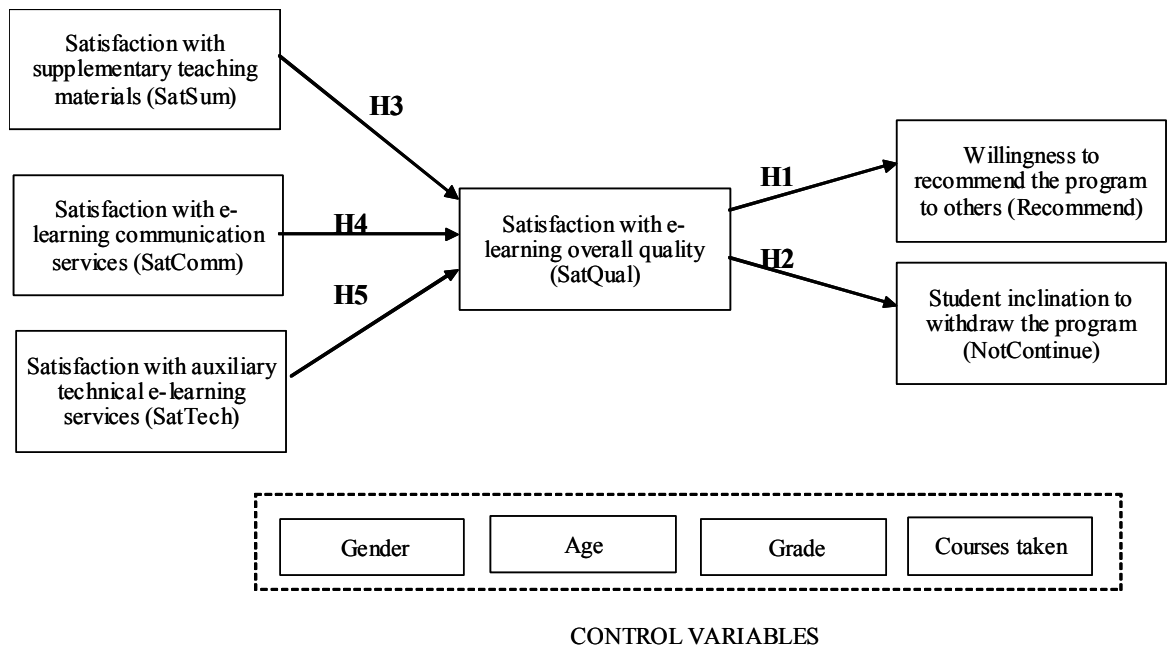

Figure 1: The Suggested Research Model

Since we would like to compare the relative contribution of different e-learning services, these services were divided to three constructs, according to the level of effort they require and the load on student attention (Simon, 1957; Davenport \& Beck, 2000, 2001):

- Supplementary teaching materials (SatSum) require the least effort of the students. These are basically materials which the course coordinator posts on the website and the students may download them.

- E-learning communication services (SatComm) enable better communication with instructors and classmates. The students may choose just to read the messages, or be actively engaged by posting messages. Usually, this communication deals with course assignments and exams. Hence, students may benefit just from tracking these messages, and even more if they post a question and get an answer to a specific problem.

- Auxiliary technical e-learning services (SatTech) include optional activities that enhance the learning process or interaction among students, and represent advanced use of e-learning. They usually entail more investment of resources by academic institutions and educators for developing and maintaining them, and they also require more efforts of the students, therefore consuming more time and attention.

The specific e-learning services which are included in each construct are depicted in appendix 1. Since student retention is influenced by many factors (Tinto, 1975; Simpson, 2003, Woodley, 2004), we do not assume direct influence of specific e-learning tool types on retention and recommendation, but rather hypothesize that satisfaction with each type of tools should increase student satisfaction with e-learning overall quality. The three hypotheses related to these constructs are:

H3: Satisfaction with e-learning supplementary teaching materials positively affects student satisfaction with e-learning overall quality.

H4: Satisfaction with e-learning communication services positively affects student satisfaction with e-learning overall quality.

H5: Satisfaction with auxiliary technical e-learning services positively affects student satisfaction with e-learning overall quality. 
Since the use of auxiliary technical e-learning services poses greater demand on student time and limited attention (Simon, 1957; Davenport \& Beck, 2000, 2001) than the other two types of services, we also suggest the following:

H5a: The impact of satisfaction with auxiliary technical e-learning services on student satisfaction with e-learning overall quality is smaller than the impact of simpler elearning services.

The model was controlled for possible influence of:

- Gender.

- Age.

- The student average grade.

- The number of successfully completed courses.

\section{Methodology}

The research population comprised of students registered in the MBA program at the Open University of Israel. The students of the MBA program, inaugurated in October 2002, may choose between a full distance learning model and a blended model which combines a few face-to-face meetings with traditional distance education tools such as books and study guides along with online learning support through course websites. The tuition is the same, regardless of the chosen mode, and the students do not have to choose their learning mode a-priori, so they may decide spontaneously whether to attend or skip a face-to-face class meeting. Many students work full time, and they chose this program due to its flexibility and distance learning option.

The research pilot included examination of the initial questionnaire by three experienced course coordinators, followed by data collection from 44 students. The results were analyzed and discussed at a seminar conducted by the Chais Research Center for the Integration of Technology in Education, at the Open University of Israel. The questionnaire was slightly adjusted according to the feedback analysis. The entire population of 1,916 students enrolled in the Open University MBA program courses in April 2006 was contacted by email and asked to answer the anonymous online survey. 390 students responded to this request. An additional 130 students answered the survey after a reminder. The total 520 answers represent a $27.1 \%$ response rate. Non response bias was assessed by comparing the early and late respondents (Armstrong \& Overton, 1977). There were no significant differences between these two groups. Construct reliability and validity were adequate, and the measurement of both is further explained in the next section.

\section{Results}

The demographic characteristics of the 520 MBA program students who answered the survey are presented in Table 1. There were no gender, age, or grade differences in the data.

\begin{tabular}{|c|c|c|c|c|c|c|c|}
\hline \multicolumn{8}{|c|}{ Table 1: Demographic characteristics of survey participants } \\
\hline \multirow[t]{2}{*}{ Gender } & Men & Women & & & & & \\
\hline & $50.8 \%$ & $49.2 \%$ & & & & & \\
\hline \multirow[t]{2}{*}{ Age } & Below 21 & $21-25$ & $26-30$ & 31-35 & $36-40$ & $41-50$ & Over 50 \\
\hline & - & $3.7 \%$ & $32.9 \%$ & $34.0 \%$ & $14.0 \%$ & $12.7 \%$ & $2.7 \%$ \\
\hline \multirow[t]{2}{*}{ Average MBA grade } & $\begin{array}{l}\text { just } \\
\text { started }\end{array}$ & $\begin{array}{l}\text { Less than } \\
70\end{array}$ & $70-75$ & 76-80 & 81-85 & 86-90 & $91-100$ \\
\hline & $18.1 \%$ & $.4 \%$ & $6.7 \%$ & $19.0 \%$ & $28.9 \%$ & $20.2 \%$ & $6.7 \%$ \\
\hline \multirow{2}{*}{$\begin{array}{l}\text { Number of completed } \\
\text { courses ( } 15 \text { courses re- } \\
\text { quired for an MBA) }\end{array}$} & & None & $\begin{array}{l}1-3 \\
\text { courses }\end{array}$ & $\begin{array}{l}4-6 \\
\text { courses }\end{array}$ & $\begin{array}{l}7-9 \\
\text { courses }\end{array}$ & $\begin{array}{l}10-12 \\
\text { courses }\end{array}$ & $\begin{array}{l}\text { Over } 12 \\
\text { courses }\end{array}$ \\
\hline & & $17.5 \%$ & $26.0 \%$ & $18.8 \%$ & $15.0 \%$ & $11.2 \%$ & $11.5 \%$ \\
\hline
\end{tabular}


Appendix 1 presents the relative contribution of various e-learning tools to learning, as perceived by the students. The students perceived supplementary teaching services (SatSum) provided by the websites, such as sample exams, as having the highest contribution to learning, with average item scores of 5.94 to 6.43 on a Likert scale of 1 to 7 . The contribution level of auxiliary communication services (SatComm) ranged from 5.07 to 5.58, whereas the perceived contribution of auxiliary technical services (SatTech) was the lowest with values of 2.47 to 4.62 .

The data was analyzed with Partial Least Square (PLS-Graph 3.00 Build 1126), which is widely used in MIS research (Gefen \& Straub, 2005). PLS is a structured equation modeling method that analyzes how the items load on their constructs simultaneously with estimating all the paths in the model. PLS estimates all paths, loadings, the Average Variance Extracted (AVE) of principal constructs, and construct reliability. Convergent and discriminant validity are shown when each item loads much higher on its assigned factor than on any other factor and when the square root of the AVE of each construct is much larger than the correlation of that construct with all other constructs (Chin, 1998; Chin, Marcolin, \& Newsted, 2003; Gefen, Straub, \& Boudreau, 2000; Gefen \& Straub, 2005). Appendix 2 contains a confirmatory factor analysis in PLS. Appendix 3 shows the mean, standard deviation, and PLS reliability along with the correlation among the constructs and their square root of the AVE. Finally, appendix 4 details the path loadings and tvalues. All the measures are above the thresholds suggested in the literature (Gefen, et al. 2000).

The standardized PLS path coefficients are shown in table 2, which shows that both retention and willingness to recommend the MBA program were influenced by student satisfaction with the overall quality of e-learning (standardized coefficients -0.272 for inclination to withdraw, and 0.399 for willingness to recommend). All three e-learning constructs significantly contributed to the over e-learning quality, but whereas the standard coefficients of SatSum and SatComm were 0.310 and 0.318 respectively, the SatTech coefficient was 0.146 . Those students who were inclined to leave the program would not recommend it to others $(-0.368)$. The number of courses taken had a strong negative influence (0.419) on student inclination to withdraw the program, and also a weak negative influence (0.096) on willingness to recommend it. All the other paths among pairs of constructs were insignificant.

\begin{tabular}{|c|c|c|c|c|c|c|c|c|c|}
\hline \multirow{2}{*}{\multicolumn{10}{|c|}{\begin{tabular}{|l|} 
\\
Path Coefficients \\
\end{tabular}}} \\
\hline & & & & & & & & & \\
\hline & NotConti & SatQual & SatTech & SatSum & CoursesT & SatComm & Grade & Gender & Age \\
\hline LoyRecmd & -0.3680 & 0.3390 & & & -0.0960 & & -0.0520 & -0.0690 & 0.0180 \\
\hline NotConti & & -0.2720 & & & -0.4190 & & 0.0110 & 0.0480 & -0.0020 \\
\hline SatQual & & & 0.1460 & 0.3100 & -0.0400 & 0.3180 & 0.0730 & -0.0130 & 0.0640 \\
\hline \multicolumn{10}{|c|}{ Path T Values } \\
\hline & NotConti & SatQual & SatTech & SatSum & CoursesT & SatComm & Grade & Gender & Age \\
\hline LoyRecmd & 7.7518 & 9.6397 & & & 2.1453 & & 1.3449 & 1.7192 & 0.4332 \\
\hline NotConti & & 6.3557 & & & 12.4376 & & 0.2581 & 1.3181 & 0.0454 \\
\hline SatQual & & & 3.4201 & 5.3277 & 1.0173 & 5.7917 & 1.9945 & 0.3552 & 1.5757 \\
\hline
\end{tabular}




\section{Discussion}

The most interesting finding of this study is that although auxiliary technical services (SatTech) significantly affected overall e-learning quality (SatQual), this influence was weaker than the influence of the other two e-learning constructs, supplementary teaching materials (SatSum) and communication services (SatComm), which represent less sophisticated tools. First, we shall discuss potential explanations as to why students perceive the more sophisticated technical eservices as less valued. Then, we will elaborate on the practical implications for academic institutions and educators.

One way to look at the students' preferences regarding e-learning services is from a satisficer perspective (Simon, 1957). The students want to successfully complete the course, while investing minimal efforts in the process. Hence, they prefer to get focused teaching materials, such as sample exams, solutions to assignments, and presentations which summarize the learning materials. They also value fast answers from the instructor to questions posted at the course discussion board, which usually refer to the assignments or the exam. Bounded rationality (Simon, 1957) also provides an explanation to this phenomenon: the students are overwhelmed with the ample learning opportunities, thus they choose the simple familiar tools. Another potential explanation is from an attention economy perspective (Davenport and Beck, 2000, 2001). The students have limited attention resources, and there are many demands on them. Therefore, even if they would like to engage in learning that is more active and explore enrichment references, they simply cannot afford to allocate the time to these activities. Sometimes, they are so busy that they are not even aware of these possibilities.

The findings of this research seem to reveal a value paradox of investment in MBA e-learning services. Although the sophisticated services require more resources, the students attribute higher value to the simple standard tools. One implication may be that institutions that cannot afford sophisticated tools may still gain much from utilizing standard e-learning tools. A second suggestion is that all academic institutions should consider this basic e-learning infrastructure as a strategic necessity for MBA programs (Neumann, 1994) due to its impact on retention and recommendation.

The implications of these findings to educators are that they should at least maintain simple course website services, such as providing auxiliary teaching materials, because the students expect to get these services, and the lack of them may impair student satisfaction, resulting in decreased retention as well as a lesser willingness to recommend the program. Instructors should use the bulletin board to notify students of relevant course information, as well as important additions to the website, to get the students' attention. Since instructor time is also a limited resource, investment of this time in sophisticated e-learning services should be carefully considered, and perhaps it should be focused on one or two advanced tools which are appropriate to the specific course and are expected to be used by the students and to create the most value for them.

\section{Conclusion}

This study examined the value of several aspects of MBA course websites to academic institutions and showed that student satisfaction with e-learning overall quality affects both student retention and loyalty, measured by willingness to recommend the program. An analysis of the relative contribution of the three types of auxiliary e-learning services on student satisfaction with elearning overall quality revealed that students valued most the simple services which did not require their active engagement in online activities. A satisficing approach, bounded rationality and limited attention resources (Simon, 1957, 1971; Davenport \& Beck, 2000, 2001) were suggested as possible explanations of this preference. 
While course discussion boards are perceived as crucial for socializing and learning (Rovai, 2002; Rovai \& Jordan, 2004; Salmon, 2004) it seems that this aspect is less important to MBA students who prefer functional forums which are focused on learning support. Future research should examine this, controlling for different study subjects, as well as culture, gender and age.

As in other online environments (Gefen, Karahanna, \& Straub, 2003), student trust in the content of diverse e-learning resources is also an issue which requires further research. Students are expected to trust website content which is provided by the teacher, but they may be hesitant to use information from peers, or external information such as newspaper articles, or commercial websites, which are commonly used in MBA studies to demonstrate practical issues.

In conclusion, course websites are important, but in order to be effective, they must be focused. They have to answer the students' needs and also consider their limited attention. "A wealth of information creates a poverty of attention" (Simon, 1971). Simple e-learning tools can provide students with reliable structured information and therefore enhance learning, satisfaction, retention and willingness to recommend the program to others.

\section{References}

Ahituv, N. (1980). A systematic approach toward assessing the value of an information system. MIS Quarterly, 4(4), 61-75.

Ahituv, N. (1989). Assessing the value of information: Problems and approaches. Proceedings of the 10th Annual International Conference on Information Systems, Boston, MA (December 1989), 315-325.

Alavi, M., \& Leidner, D. E. (2001). Research commentary: Technology mediated learning - a call for greater depth and breadth of research. Information Systems Research, 12(1), 1-10.

Alavi, M., Marakas, G. M., \& Yoo, Y. (2002). A comparative study of distributed learning environments on learning outcomes. Information Systems Research, 13(4), 404-415.

Armstrong, J. S., \& Overton, T. S. (1977). Estimating nonresponse bias in mail surveys. Journal of Marketing Research, 14 (August), 396-402.

Chin, W. W. (1998). Issues and opinions on structural equation modeling. MIS Quarterly, 22(1), 7-16.

Chin, W. W., Marcolin, B. L., \& Newsted, P. R. (2003). A partial least squares latent variable modeling approach for measuring interaction effects: Results from a Monte Carlo simulation study and an electronic mail adoption study. Information Systems Research, 14(2), 189-217.

Davenport, T. H., \& Beck, J. C. (2000). Getting the attention you need. Harvard Business Review, 78(5), $118-126$.

Davenport, T. H., \& Beck, J. C. (2001). The attention economy: Understanding the new currency of business. Boston, MA: Harvard Business School Press.

Eastmond, D. V. (1995). Alone but together: Adult distance study through computer conferencing. Cresskill, NJ: Hampton Press.

Gefen, D., Karahanna, E., \& Straub, D.W. (2003). Trust and TAM in online shopping: An integrated model. MIS Quarterly, 27(1), 51-90.

Gefen, D., \& Straub, D. W. (2005). A practical guide to factorial validity using PLS-graph: Tutorial and annotated example. Communications of the AIS, 16(5) 91-109.

Gefen, D., Straub, D. W., \& Boudreau, M. C. (2000). Structural equation modeling and regression: Guidelines for research practice. Communications of the AIS, 4(7), 1-78. Retrieved November 28, 2006 from http://www.cis.gsu.edu/ dstraub/Papers/Resume/Gefenetal2000.pdf

Guri-Rosenblit, S. (2005). Eight paradoxes in the implementation process of e-learning in higher education. Higher Education Policy, 18(1), 5-29. 
Is There a Value Paradox of E-learning in MBA Programs?

Hiltz, S. R., \& Turoff, M. (2002). What makes learning networks effective? Communications of the ACM, 45(4), 56-59.

Hiltz, S. R., \& Turoff, M. (2005). Education goes digital: The evolution of online learning and the revolution in higher education. Communications of the ACM, 48(10), 59-64.

Hirschheim, R. (2005). The internet-based education bandwagon: Look before you leap. Communications of the $A C M, 48(7), 97-101$.

Levy, Y. (2006). The top 10 most valuable online learning activities for graduate MIS students. International Journal of Information and Communication Technology Education, 2(3), 27-44.

Levy, Y. (2007). Comparing dropouts and persistence in e-learning courses. Computers \& Education, 45(2), 185-204.

Neumann, S. (1994). Strategic information systems: Competition through information technologies. New York: Macmillan Publishing.

Ronen, B., Pliskin, J. S, \& Pass, S. (2006). Focused operations management for health services organizations. San Francisco: Jossey-Bass, a Wiley Imprint.

Rovai, A. P. (2002). Building sense of community at a distance. International Review of Research in Open and Distance Learning, 3(1), Retrieved November 28, 2006 from www.irrodl.org/index.php/irrodl/article/viewPDFInterstitial/79/153

Rovai, A. P., \& Jordan, H. (2004). Blended learning and sense of community: A comparative analysis with traditional and fully online graduate courses. International Review of Research in Open and Distance Learning, 5(2), Retrieved November 28, 2006 from http://www.irrodl.org/index.php/irrodl/article/view/192/274

Salmon, G. (2004). E-moderating: The key to teaching and learning online (2nd ed.). London, UK: RoutledgeFalmer, Taylor and Francis Group.

Simon, H. A. (1971). Designing organizations for an information-rich world. In M. Greenberger (Ed.), Computers, communications and the public interest (pp.40-41). Baltimore, MD: Johns Hopkins Press.

Simon, H. A. (1957). Models of man: Social and rational. New York: John Wiley and Sons.

Simpson, O. (2003). Student retention in online, open and distance learning, London and Sterling, VA: Kogan Page.

Tinto, V. (1975). Dropout form higher education: A theoretical synthesis of recent research. Review of Education Research, 45(1), 89-125.

Tresman, S. (2002). Towards a strategy for improved student retention in programmes of open, distance education: A case study from the Open University UK. International Review of Research in Open and Distance Learning, 3(1). Retrieved November 28, 2006 from http://www.irrodl.org/index.php/irrodl/article/view/75/544

Woodly, A. (2004). Conceptualizing student dropout in part-time distance education: Pathologizing the normal? Open Learning, 19(1), 47-63. 


\section{Appendix 1. Relative Perceived Contribution of E-Learning Tools}

\begin{tabular}{|l|l|c|c|}
\hline Construct & Item & Average & $\begin{array}{c}\text { Standard } \\
\text { deviation }\end{array}$ \\
\hline \multirow{2}{*}{$\begin{array}{l}\text { SatSum } \\
\text { Supplementary } \\
\text { teaching services }\end{array}$} & E6.05 Sample exams & 6.43 & 1.08 \\
\cline { 2 - 4 } & E6.06 Task solutions & 6.35 & 1.10 \\
\cline { 2 - 4 } SatComm & E6.08 Meeting summaries and presentations & 5.94 & 1.42 \\
\hline $\begin{array}{l}\text { Auxiliary communication } \\
\text { services }\end{array}$ & E6.09 Discussion board & 5.58 & 1.49 \\
\cline { 2 - 4 } SatTech & E6.01 Bulletin board & 5.07 & 1.61 \\
$\begin{array}{l}\text { Auxiliary } \\
\text { technical services }\end{array}$ & E6.04 Glossary of course terms & 4.62 & 1.80 \\
\cline { 2 - 4 } & E6.07 Electronic reader & 4.51 & 1.90 \\
\cline { 2 - 4 } & E6.02 Discussion board group activities & 4.27 & 1.87 \\
\cline { 2 - 4 } & E6.03 Links to other websites & 4.17 & 1.75 \\
\cline { 2 - 4 } & E6.13 Current newspaper articles examples & 4.02 & 1.86 \\
\cline { 2 - 4 } & E6.15 Course instant messaging tool & 2.89 & 1.97 \\
\cline { 2 - 4 } & E6.10 Personal notepad & 2.47 & 1.75 \\
\hline
\end{tabular}




\section{Appendix 2. Confirmatory Factor Analysis in PLS}

\begin{tabular}{|c|c|c|c|c|c|c|}
\hline & 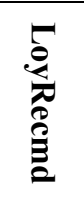 & 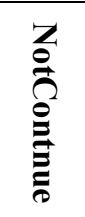 & 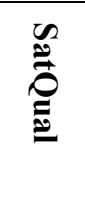 & $\begin{array}{l}\mathscr{2} \\
\stackrel{0}{0} \\
\stackrel{0}{ٍ}\end{array}$ & $\begin{array}{l}\mathscr{\mathscr { N }} \\
\stackrel{\tilde{\omega}}{\Xi} \\
\Xi\end{array}$ & $\begin{array}{l}\mathscr{\mathscr { N }} \\
\stackrel{\tilde{\Xi}}{\Xi} \\
\stackrel{\Xi}{\Xi}\end{array}$ \\
\hline $\begin{array}{l}\text { K2.1 I will recommend the Open University MBA pro- } \\
\text { gram to others }\end{array}$ & 0.98 & -0.40 & 0.44 & 0.27 & 0.24 & 0.22 \\
\hline $\begin{array}{l}\text { K2.2 I will encourage others to study in the Open Uni- } \\
\text { versity MBA program }\end{array}$ & 0.98 & -0.40 & 0.43 & 0.27 & 0.24 & 0.22 \\
\hline $\begin{array}{l}\text { K2.3 If my friends were looking for an MBA program, I } \\
\text { would recommend the Open University MBA program }\end{array}$ & 0.97 & -0.42 & 0.40 & 0.27 & 0.23 & 0.24 \\
\hline $\begin{array}{l}\text { K1.1 I will probably successfully complete the MBA } \\
\text { studies }\end{array}$ & 0.39 & -0.82 & 0.27 & 0.14 & 0.22 & 0.16 \\
\hline $\begin{array}{l}\text { K1.2 I will probably continue the MBA studies in an- } \\
\text { other institution }\end{array}$ & -0.34 & 0.83 & -0.26 & -0.07 & -0.22 & -0.15 \\
\hline K1.3 I will probably have to quit the MBA studies & -0.31 & 0.87 & -0.23 & -0.12 & -0.23 & -0.19 \\
\hline $\begin{array}{l}\text { A4.1 The academic level of the course websites' content } \\
\text { is adequate }\end{array}$ & 0.38 & -0.31 & 0.79 & 0.32 & 0.39 & 0.39 \\
\hline $\begin{array}{l}\text { A } 4.2 \text { The Information provided in the course websites is } \\
\text { accurate }\end{array}$ & 0.34 & -0.27 & 0.70 & 0.22 & 0.39 & 0.33 \\
\hline A4.3 The content of the course websites is reliable & 0.30 & -0.29 & 0.73 & & & 0.36 \\
\hline $\begin{array}{l}\text { E1 The Course websites help me overcome difficulties } \\
\text { with my studies }\end{array}$ & 0.28 & -0.12 & 0.75 & 0.39 & 0.35 & 0.42 \\
\hline $\begin{array}{l}\text { E2 So far, I am satisfied with the usefulness of the } \\
\text { course websites }\end{array}$ & 0.30 & -0.22 & 0.78 & 0.33 & 0.44 & 0.46 \\
\hline $\begin{array}{l}\text { E3 I am satisfied with the level of learning support pro- } \\
\text { vided by the course websites }\end{array}$ & 0.32 & -0.23 & 0.83 & 0.31 & 0.40 & 0.43 \\
\hline E4 the course websites enrich my learning experience & 0.39 & -0.14 & 0.74 & 0.40 & 0.36 & 0.42 \\
\hline $\begin{array}{l}\text { E5 I was disappointed with the service provided by the } \\
\text { course websites }\end{array}$ & -0.24 & 0.25 & -0.61 & -0.18 & -0.33 & -0.21 \\
\hline $\begin{array}{l}\text { E6.02 Discussion board group activities level of contri- } \\
\text { bution to learning }\end{array}$ & 0.15 & -0.02 & 0.32 & 0.71 & 0.30 & 0.31 \\
\hline $\begin{array}{l}\text { E6.03 Links to other websites level of contribution to } \\
\text { learning }\end{array}$ & 0.22 & -0.15 & 0.32 & 0.77 & 0.26 & 0.36 \\
\hline $\begin{array}{l}\text { E6.04 Glossary of course terms level of contribution to } \\
\text { learning }\end{array}$ & 0.21 & -0.15 & 0.31 & 0.72 & 0.37 & 0.33 \\
\hline E6.07 Electronic reader level of contribution to learning & 0.23 & -0.14 & 0.30 & 0.72 & 0.38 & 0.22 \\
\hline E6.10 Personal notepad level of contribution to learning & 0.14 & 0.08 & 0.08 & 0.50 & 0.07 & 0.19 \\
\hline $\begin{array}{l}\text { E6.13 Current newspaper articles examples level of } \\
\text { contribution to learning }\end{array}$ & 0.23 & -0.12 & 0.29 & 0.72 & 0.32 & 0.27 \\
\hline $\begin{array}{l}\text { E6.15 Course instant messaging tool level of contribu- } \\
\text { tion to learning }\end{array}$ & 0.11 & 0.05 & 0.20 & 0.59 & 0.12 & 0.20 \\
\hline E6.05 Sample exams level of contribution to learning & 0.21 & -0.25 & 0.47 & 0.28 & 0.89 & 0.32 \\
\hline E6.06 Task solutions level of contribution to learning & 0.19 & & & 0.29 & 0.88 & 0.39 \\
\hline $\begin{array}{l}\text { E6.08 Meeting summaries and presentations level of } \\
\text { contribution to learning }\end{array}$ & 0.20 & -0.24 & 0.37 & 0.50 & 0.73 & 0.37 \\
\hline E6.09 Discussion board level of contribution to learning & 0.19 & -0.22 & 0.49 & 0.37 & 0.44 & 0.89 \\
\hline E6.01 Bulletin board level of contribution to learning & 0.22 & -0.10 & 0.38 & 0.32 & 0.27 & 0.81 \\
\hline
\end{tabular}




\section{Appendix 3. Correlation Matrix, Descriptives and Average Variance Extracted of Principal Components}

Mean, Standard Deviation, and PLS reliability together with the correlation among the constructs and their square root of the AVE. Correlations of latent variables and Square Root of the AVE are presented in the diagonals.

\begin{tabular}{|c|c|c|c|c|c|c|c|c|c|c|c|c|c|}
\hline & $\begin{array}{l}3 \\
\stackrel{3}{0} \\
\stackrel{0}{*}\end{array}$ & 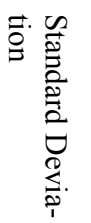 & 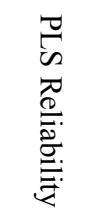 & $\begin{array}{l}5 \\
0 \\
\stackrel{0}{0} \\
0 \\
0 \\
0 \\
0\end{array}$ & 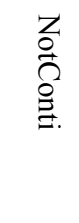 & $\begin{array}{l}\mathscr{N} \\
\stackrel{0}{0} \\
\stackrel{\mathscr{D}}{0}\end{array}$ & 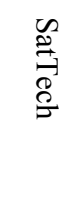 & $\begin{array}{l}\tilde{W} \\
\tilde{\Xi} \\
\tilde{\Xi} \\
\Xi\end{array}$ & 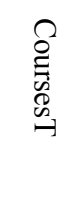 & $\begin{array}{l}\mathscr{N} \\
\stackrel{\tilde{\Xi}}{\tilde{\Omega}} \\
\stackrel{\Xi}{\Xi}\end{array}$ & $\begin{array}{l}\stackrel{Q}{0} \\
\text { مै }\end{array}$ & $\begin{array}{l}\stackrel{Q}{0} \\
\stackrel{0}{0} \\
\stackrel{0}{9}\end{array}$ & $\underset{\substack{\infty \\
0}}{\overrightarrow{0}}$ \\
\hline LoyRecmd & 4.920 & 1.764 & .99 & .978 & & & & & & & & & \\
\hline NotConti & 1.883 & 1.140 & .88 & -0.419 & .840 & & & & & & & & \\
\hline SatQual & 5.605 & 0.943 & .91 & 0.433 & -0.306 & .743 & & & & & & & \\
\hline SatTech & 3.849 & 1.261 & .86 & 0.276 & -0.127 & 0.407 & .682 & & & & & & \\
\hline SatSum & 6.240 & 0.995 & .87 & 0.242 & -0.266 & 0.509 & 0.412 & .837 & & & & & \\
\hline CoursesT & 3.11 & 1.608 & $\begin{array}{r}\text { Single } \\
\text { item }\end{array}$ & 0.064 & -0.435 & 0.089 & 0.024 & 0.153 & 1.000 & & & & \\
\hline SatComm & 5.322 & 1.324 & .84 & 0.232 & -0.196 & 0.513 & 0.405 & 0.427 & 0.107 & .853 & & & \\
\hline Grade & 3.29 & 1.855 & $\begin{array}{r}\text { Single } \\
\text { item }\end{array}$ & 0.048 & -0.262 & 0.172 & 0.018 & 0.186 & 0.544 & 0.190 & 1.000 & & \\
\hline Gender & 1.49 & 0.500 & $\begin{array}{r}\text { Single } \\
\text { item }\end{array}$ & -0.077 & 0.022 & 0.030 & -0.053 & 0.095 & 0.043 & 0.111 & 0.034 & 1.000 & \\
\hline Age & 4.07 & 1.167 & $\begin{array}{r}\text { Single } \\
\text { item }\end{array}$ & 0.057 & -0.052 & 0.032 & 0.059 & -0.058 & 0.072 & -0.073 & 0.000 & -0.230 & 1.000 \\
\hline
\end{tabular}

\section{Appendix 4. Path Loadings}

\begin{tabular}{|c|c|c|c|c|c|c|c|}
\hline Construct & Item & Loading & T-value & Construct & Item & Loading & T-value \\
\hline \multirow[t]{3}{*}{ LoyRecmd } & K2.3 & 0.9687 & 232.9402 & \multirow[t]{6}{*}{ SatTech } & E6.03 & 0.7749 & 34.8373 \\
\hline & $\mathrm{K} 2.2$ & 0.9825 & 391.5986 & & E6.04 & 0.7205 & 28.1020 \\
\hline & K2.1 & 0.9814 & 395.8274 & & E6.07 & 0.7201 & 24.7176 \\
\hline \multirow[t]{3}{*}{ NotConti } & K1.1 & -0.8194 & 35.8082 & & E6.02 & 0.7080 & 25.1343 \\
\hline & K1.2 & 0.8297 & 35.6975 & & E6.10 & 0.5005 & 10.7495 \\
\hline & K1.3 & 0.8711 & 46.3994 & & E6.13 & 0.7209 & 27.7832 \\
\hline \multirow[t]{8}{*}{ SatQual } & E2 & 0.7756 & 31.2346 & \multirow[t]{3}{*}{ SatSum } & E6.15 & 0.5858 & 14.8927 \\
\hline & A4.1 & 0.7873 & 24.2300 & & E6.05 & 0.8930 & 59.6640 \\
\hline & $\mathrm{A} 4.2$ & 0.7046 & 22.0168 & & E6.06 & 0.8764 & 36.0989 \\
\hline & E5 & -0.6148 & 12.6230 & \multirow[t]{2}{*}{ SatComm } & E6.08 & 0.7310 & 15.8793 \\
\hline & A 4.3 & 0.7285 & 24.7419 & & E6.09 & 0.8914 & 50.5500 \\
\hline & E3 & 0.8288 & 51.4683 & & & & \\
\hline & E1 & 0.7459 & 28.0785 & & & & \\
\hline & E4 & 0.7390 & 22.2062 & & & & \\
\hline
\end{tabular}




\section{Biography}

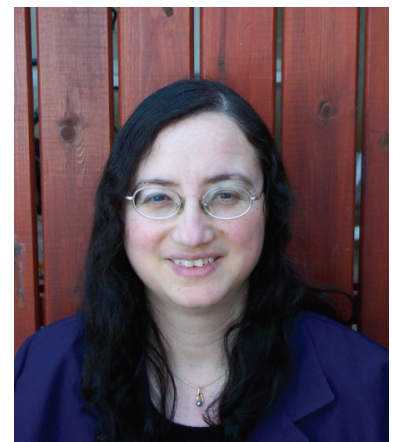

Nitza Geri is Head of Undergraduate Management Studies at the Department of Management and Economics at The Open University of Israel and a member of the Chais Research Center for the Integration of Technology in Education. She holds a B.A. in Accounting and Economics, an M.Sc. in Management Sciences and a Ph.D in Technology and Information Systems Management from Tel-Aviv University. She is a CPA (Israel) and prior to her academic career she had over 12 years of business experience. Her research interests focus on various aspects of the value of information, and information systems adoption and implementation, which include: strategic information systems, ebusiness, value creation and the Theory of Constraints, managerial aspects of e-learning systems adoption and use.

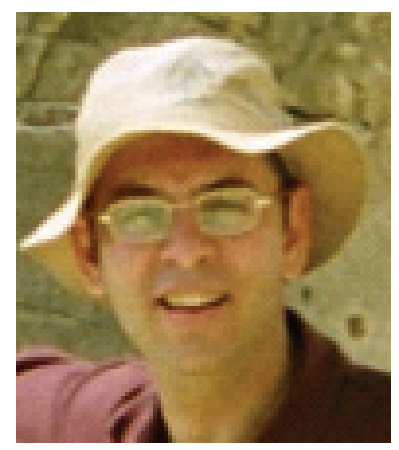

David Gefen is an Associate Professor of MIS at Drexel University, where he teaches at the MBA level Strategic Management of IT, Database Analysis and Design, and Programming languages. He received his Ph.D. in CIS from Georgia State University and a Master of Sciences from Tel-Aviv University. David has conducted extensive research on issues relating to the adoption, implementation and use of advanced computer technologies. His wide interests in IT adoption stem from his 12 years of experience in developing and managing large information systems, including the ongoing management of a large state-of-the-art logistics system. His research specialization is in IT adoption, the Internet, culture and gender effects, and e-trust. His current research interests focus on psychological and relational processes involved in the successful implementation of technological innovations. His research findings have been published in leading academic and professional journals, including the MISQ, ISR, Database, Omega, JAIS, and CAIS. Dr. Gefen is also the author of a textbook on VB.NET programming, and a SE at Database. 